\title{
A Forest of Contradictions: Producing the Landscapes of the Scottish Highlands
}

\author{
Paul Robbins and Alistair Fraser
}

Department of Geography, Ohio State University, Columbus, OH, USA; probbins@geography.ohio-state.edu, afraser@geography.ohio-state.edu

\begin{abstract}
While total global forest cover is decreasing, in many parts of the world forests are on the rebound. Uncritical examinations of this phenomenon credit the benign diffusion of capitalist development for this "forest transition." More critical readings of this question-including green Marxian and poststructuralist approaches_-might conclude something very different, however. In this paper, we explore the question of expanding forest cover, using the case of the Scottish Highlands, where forestland has tripled since the 1920s, in an attempt to critically explain regional land-cover change. Drawing upon historical sources and Scottish Executive and Forestry Commission data, we examine the specific environments currently forming in the Highlands under conditions of economic change. We conclude that two divergent forestry practices and ecologies have been formed in the wake of economic restructuring: those geared towards industrial production and those targeted at consumption through ecotourism. We conclude, therefore, that capitalism's spatial fix to declining industrial power in the region is an inherently ecological one that takes the form of "schizophrenic forestry," in which forest expansion leads to the rise of degraded monocultures alongside "pristine" sites of conservation.
\end{abstract}

SNH's [Scottish Natural Heritage] vision is for Scotland's forests and woodlands to develop as a diverse resource that is productive, ecologically robust, scenically attractive and provides people with pleasure and recreational opportunities. (Scottish Natural Heritage 2001)

The development of culture and of industry in general has ever evinced itself in such energetic destruction of forests that everything done by it conversely for their preservation and restoration appears infinitesimal. (Marx 1967b:248)

Total global forest cover is estimated to have decreased more than $18 \%$ since 1700 . That pattern is marked, however, by gross spatial and temporal unevenness: while deforestation in the rest of the world has accelerated since the 1950s, forests in North America and Europe have slowly begun to expand, reclaiming regions of previous decline and colonizing areas long free from tree cover (Richards 1990). What can political-economic analysis contribute to explaining these changes, and what insight does critical scholarship provide? Where do forests expand-and why? 
Less critical accounts born of ecological modernization theory point to a forest transition that inevitably follows the development of urbanized industrial workforces and the disintensification of agricultural landscapes, allowing the return of forests in rural areas. By this way of thinking, the return of forests on the global periphery (South) will simply follow that of forests in the core (North) as the benefits of development are extended through globalization and rising gross national product. But to what degree does postindustrial development of nations such as the US and Japan depend directly upon the continued exploitation of primary products in the developing world? Is the reforestation of New England not tied to the deforestation of Indonesia?

In answer to such a question, explanation might take a green materialist form and follow an interest in capitalism's "energetic destruction." This approach might emphasize "the second contradiction of capitalism" (following O'Connor 1996) and the economy's "metabolic rift" (after Foster 2000:157), both of which look to the crises of underproduction that emerge from capitalist ecology. These, it might be argued, drive patterns of native forest-cover decline and the expansion of invasive species and degraded monocultures typical of industrial forestry. Reforestation of the global North follows directly from deforestation of the global periphery, as the development of culture and of industry inevitably drives towards scarcity and crisis. Yet forests are returning in some parts of the periphery, and their preservation has become the driving development plan for many newly industrializing nations. In building ecotourist economies to meet the demands of a greening World Bank, many countries have seen increases in forest (De Camino et al 2000; Gautam et al 2000; Kumar et al 2000; Lele et al 2000).

Another approach to the question, therefore, might follow poststructural political ecology, emphasizing Escobar's (1996) view that the environment represents a second form of capital, and interrogate the enthusiasm of organizations such as Scottish Natural Heritage (SNH) and the economic "opportunities" they create through conservation. This approach would take the form of a critique of green capitalism, exploring the economy's ecological phase and looking to the recovery of previously declining forest landscapes marketed in an era of consumer conservation (Escobar 1996).

While these critical approaches emphasize capitalism's creativity, one approach points critique towards predicting and explaining degradation of existing ecosystems, while the other points to the creation of new environments: the first towards capitalism's destructive power, the latter to its generative power. One is structural in nature, unearthing the laws of capital mobility that create hauntingly familiar scenarios of degradation over time. The other is poststructural 
and emphasizes the inventive discursive power of society and economy, pointing towards something altogether new in the early 21st century.

In this paper, we argue that only through a richer exploration of the simultaneity of such processes in capitalist ecology can a clear explanation of land-cover change emerge. We argue that the creative acts in capitalism's ecological phase must accompany environmental destruction and that, for any truly dialectic explanation, green Marxism and poststructural political ecology must attend to the spatial and scalar aspects of land-use economies that connect apparently contradictory land-cover changes.

We make this argument by examining the case of the Scottish Highlands (Figure 1). Over the last millennium, this region has undergone constant ecological transformation, turning from complex forestland to heathland and pasture and back to forest again. In particular, the return to the region of "Caledonian" forests, dominated by Scots pine (Pinus sylvestris), after an absence of many centuries raises questions about contradictions in capitalist accumulation and the relationship of ecological decline to environmental reinvention and creation. The return of these native forests has received much popular and critical attention both inside and outside Scotland, with both conservationists and critical scholars expressing an interest in the constructed and introduced nature of indigenous trees (Hand 2000; Toogood 1995).

The relationship between this recent environmental change and other transformations of the Scottish economy remains somewhat elusive, however. Economic imperatives in the highlands-ranging from commercial forestry and sheep-farming to deer-hunting-have repeatedly led to new land-use practices and landscapes, including the rise of monocultural industrial forestry. At the same time, land covers produced in each era of economic change over the last two centuries have created barriers for future economic growth, leading to new demands for landscape transformation and new regimes of development. Economic crisis and landscape are linked, therefore, but in no simple way.

Drawing upon historical sources and Scottish Executive and Forestry Commission data, we explore the cultural economics of landcover transformation in the Scottish highlands. Evaluating James O'Connor's thesis of underproduction and Escobar's (1996) notion of postmodern ecological capital to explain landscape change in Scotland, we conclude that land-cover change like the expansion of Scottish forests can only be explained through reference to capitalism's ongoing drive for a spatial fix (following Harvey 1982), which unevenly develops the specific ecologies of the region, simultaneously producing two very different forms of forest. 


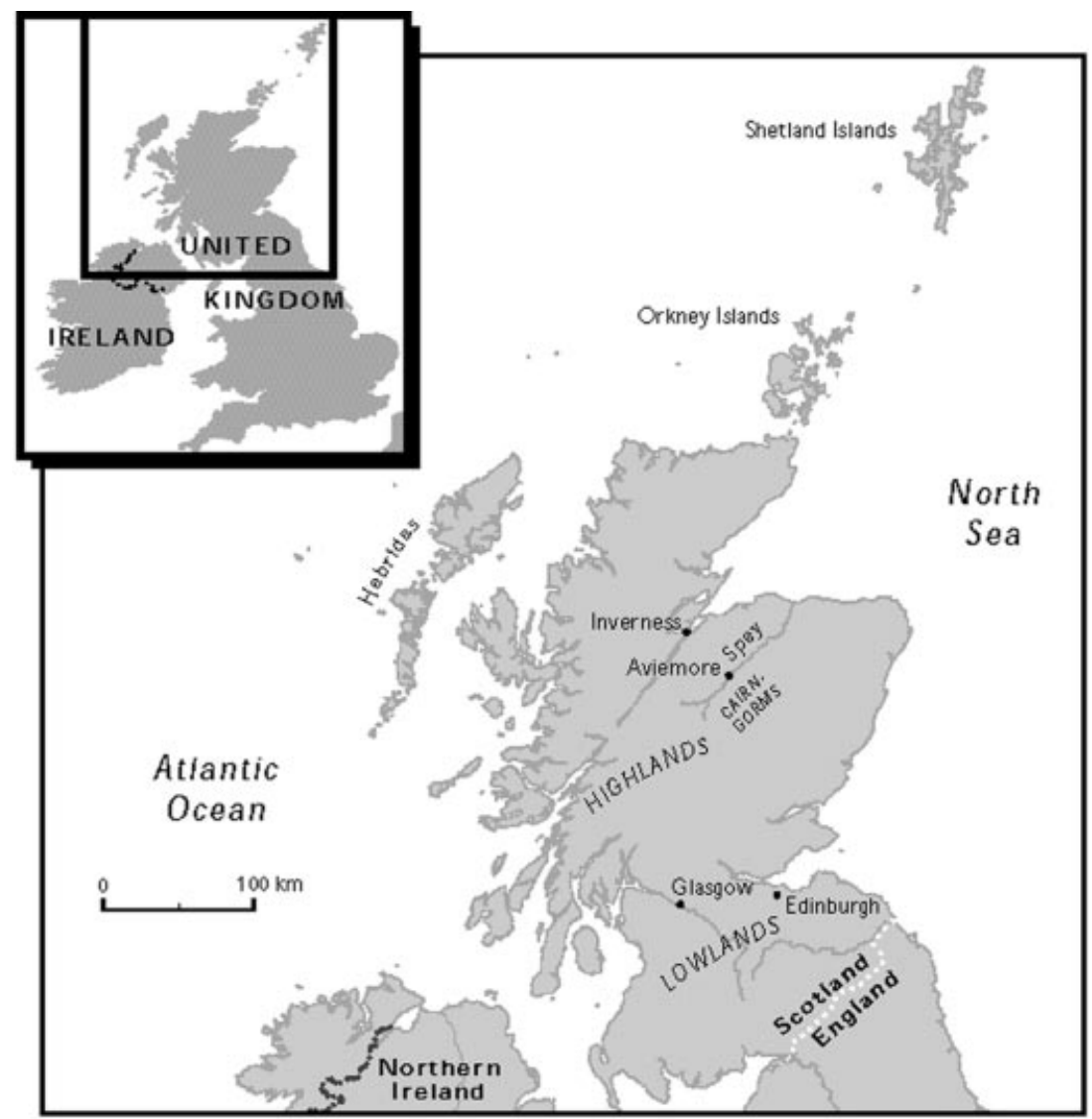

Figure 1:

The paper is divided into five parts. In the first section, we briefly examine the arguments of O'Connor, Escobar, and others, highlighting the tensions between varying interpretations of environmental change. Second, we briefly review the ecological history of the Scottish highlands, showing the rapid changes in the land that accompanied capitalist development in Scotland. In the third and fourth sections, we explore the return of forests to the highlands through both the afforesting efforts of industrial forestry-marked by plantation monoculture-and the simultaneous reforestation of diverse Caledonian forests. Here, we argue that land-cover changes are explained by the relationship between capitalism, nationalism, and the romantic landscapes of imagined history. We conclude, therefore, by emphasizing the simultaneity of creative and destructive ecologies in capitalist development and the need to examine the spatiality of 
economic and ecological change for any critical account of land-cover change.

\section{Competing Accounts of Land-Cover Change}

Explaining land-cover change is a hallmark of geographic scholarship. The conversion of farmland to suburban sprawl, forests to pasture, and grassland to cropland is a preoccupation of an increasingly wellorganized wing of environment/society research in the field (Meyer and Turner 1994; Turner et al 1990). Even so, explaining the expansion of forests is not a traditional focus of analysis, since the attention of research has historically been focused on the disappearance and degradation of such systems (Marsh 1965). The rise of critical scholarship on cultural landscape (Mitchell 1998) and environmental transformation (Blaikie 1999; Bryant and Bailey 1997), however, suggest that such processes are well worthy of investigation, enabling an emergent "political theory of social nature" (following Castree and Braun 1998:33), which focuses on the creation of new natures.

\section{Forests and Modernization}

Outside of critical scholarship, work on reforestation (defined as the return of forests to areas that had previously been deforested) and afforestation (the establishment of forests on nonforested land) has centered around ideas in ecological modernization, specifically the notion of "the forest transition" (Mather and Needle 1998; Walker 1993). Here, as alternative economic opportunities emerge in urban labor markets, intensive land uses such as farming are theorized to fall away in rural areas, and land is converted to forest over time. Under conditions of decapitalization and rising opportunity costs for labor, landowners are theorized to resort to extensive land uses, specifically forestry. The inevitable product of capitalist economic development, then, is the extensification of rural economies and the return of forests, as has most apparently been the case in the US and northern Europe.

But the relationship of such transitions to the movement of international capital and labor is poorly addressed in such a scenario. Although Rudel, Perez-Lugo, and Zichal (2000) have pointed out that greater integration into international labor markets and low returns from agricultural production in global markets may increase the rate of reforestation, as occurred in Puerto Rico, the forest transition approach to reforestation pays little attention to global markets. Moreover, it has yet to examine reforestation and afforestation in the wake of international lending initiatives and ecotourist development activity. The exploitative nature of ecological extraction is therefore opaque in such an approach, and the image of reforestation remains 
a passive one that portrays the return of forests as a slow and natural transition, free of struggle.

\section{Reforestation and Exploitative Production}

Materialist accounts, on the other hand, offer a somewhat different view of forest-cover change, pointing to forces of degradation and struggles over ecology's reformation. Following Marx's (1967a:177) observation that in laboring, man [sic] "acts upon the external world and, changing it, ... at the same time changes his own nature," green Marxist accounts begin from the notion of metabolism (Stoffwechsel) and the suggestion that nature and society are simultaneously produced (Foster 2000; Smith 1996a). The social relations of production are tied, therefore, to the metabolism of the conditions of production, including the quality of air, soil, water, biota, and human health. Under capitalism, this relationship must be exploitative and draw surpluses from labor and nature, inevitably leading to contradiction.

Thus, James O'Connor (1996) suggests that current relations to nature must drive a "second contradiction of capitalism," since the production of surplus value depends on overextraction from environmental systems in the race for marginal surpluses as the rate of profit for commodities falls. Like Marx's first contradiction-where appropriation leads to overproduction, shortfall of demand, and efforts by firms to restructure and lower costs-O'Connor's second contradiction also leads to crisis. Here, overexploitation of nature leads to a crisis of underproduction, when nature can no longer provide free subsidies into the economy. Drawing on the notion of metabolism, then, this work projects the second contradiction of capitalism as an iron law of materialism, highlighting the destructive power of the economy (Foster 2000; O'Connor 1994, 1996).

In the case of global forest landscapes, such an approach suggests that we look towards the extractive pressure of capitalism's drive for surplus in forestry and the self-destructive depletion of forest production for a global market. Contractions in forest cover in the global South are here seen in terms of Northern demand, and the expansion of new forests is queried in productive terms: are these forests truly biodiverse, or do they represent the depleted monocultures of an industrialized environment? How were they expropriated from their noncapitalist or precapitalist managers? Does depletion of forests or forest ecosystems lead to crises of underproduction, such that future productivity is hamstrung by past degradation?

\section{Afforestation and Ecological Consumption}

At the same time, however, an understanding that nature is culturally produced for consumption (Wilson 1992) might lead to a second, somewhat different set of questions. If wilderness is produced, just 
like a city, no state of nature is necessarily any more natural than another, and pristine states become difficult to distinguish from degraded ones (Cronon 1995; Williams 1973). This understanding raises questions about capitalism's inevitable degrading power and is bolstered by emergent understandings of ecological process that point to instability, surprise, and the multiple equilibrium states of natural systems (Demeritt 1994; Kepe and Scoones 1999; Scoones 1999; Zimmerer 1994). The market for produced wilderness and green space is such that the creative powers of capitalism increasingly turn towards their production. Global conservation efforts, though often posing a serious threat to the survival of local people, are nevertheless vehicles for the restoration of natural systems (Zimmerer 2000).

The production of this "postmodern form of ecological capitalism," as Escobar (1996:56) observes, leads to both new discourses of nature and altogether new landscapes. Local environmental knowledges, indigenous people, and ecological systems in their pristine form become reservoirs of value that might be produced and consumed for profit (Escobar 1996). In the case of forest-cover change, this suggests that we look to the artificial nature of indigenous forests and the way emergent land covers are discursively and materially created as a new form of capital.

Thus, the "production of nature" (Smith 1996a) points towards a tension: both the inevitability of environmental decline in production and the certainty of environmental reproduction for consumption are illuminated. This tension is reflected in cases such as the Scottish highlands, where the history of landscape change suggests both the creative and destructive powers of capitalism and points towards the simultaneity of such processes in resolving the ongoing crises in the regional economy. As we will argue here, a richer understanding of real forest-cover change requires an attention both to forests as sites of production and consumption and to the creation of competing kinds of forests in the resolution of economic contradiction.

\section{The Rise and Fall of Highland Ecologies}

The current land-cover changes occurring in the Highlands are prefigured by vast prior reorganizations of the economy and ecology. As noted elsewhere (see, for example, Turnock 1995; Whyte and Whyte 1991), the long historical shift from cattle- to sheep-farming and then to deer forestry had significant impacts upon the Highland landscape and political economy. This section briefly surveys these major transformations.

\section{0s-1870: Commercialization and Expropriation}

Based, in the medieval period, on cattle-rearing, the Highland economy underwent major changes in the 18th century. With 
industrialization and urbanization in Britain leading to rising wool prices and an increase in the demand for meat products, land values in the region changed. Land once used for the rearing of cattle was let at twice or four times the rent when grazed with sheep, such that, by the 1790s, large portions of the Highlands had been converted into sheep pasturage (Whyte and Whyte 1991). Tenant farmers were often forcibly moved off the land as a result, and landowners consolidated the landscape into large holdings in an attempt to realize economies of scale (Turnock 1995).

However, this new economy and ecology, dominated by sheepfarming, eventually experienced the consequences of its incorporation into the global economy. As stocks from New Zealand and Australia flooded the global market in the 1870s, wool and mutton prices plummeted, sheep prices fell $70 \%$ between 1860 and 1900, and the sheep population declined dramatically in the period between 1880 and 1906 (Whyte and Whyte 1991). Faced with falling earnings, landowners in the Highlands turned to alternative sources of income.

\section{0-1921: Deer-Stalking Landscapes}

The population of indigenous red deer (Cervus elaphus) was at an historical low by 1870, their numbers having declined in competition with the sheep economy (Smith 1993:93). However, as hill land came to be worth as much as $50 \%$ more under hunted deer than sheep, landowners shifted their emphases towards the creation of "deer forests" (Innes 1983), and red deer re-emerged on the Highland landscape. New and extensive "sporting estates"-large areas of privately owned or managed land used mainly or partly for sport, including fishing, deer-stalking, or game-bird shooting-began to increase in size and number throughout the Highlands. In 1790, only nine forests or estates existed in all of Scotland. By 1883, the number had reached 99, and totalled 203 in Highland Scotland by 1912 (Innes 1982:141). In extent, such terrain amounted to approximately 1 million hectares (ha) in 1890; by 1910 it totalled around 1.5 million ha (Smith 1993:95).

This shift was facilitated by the advent of rail, which created a bridge between the urban elite and rural areas as the British railway network expanded deep into the Highlands. As the hills, until this point largely isolated from the day-to-day goings on of southern Britain, were now within daily reach of Britain's leisured, wealthy class, the switch from sheep pasture to deer-stalking terrain was made complete.

\section{A History of Production and Consumption}

In these transformations, we can see traces of processes described by green Marxists. The ecological transformations of the Highlands are 
clearly tied to economic crisis. The fall in global meat prices is tied to the return of native deer, for example. And, as O'Connor might predict, environmental degradation in the 1700s did apparently provide barriers to the area's transformation into sheep country in the early 18th and 19th centuries; consolidation of large holdings required the coercive displacement of extensive semiforested pasturage. So, too, the region's transformation into sheep farms provided a barrier to later accumulation; deer-stalking was impossible in the absence of deer. Even so, the decline of sheep farming in the 19th century, though often attributed to "overgrazing," has been experimentally demonstrated to have had little or nothing to do with degeneration of soil or biota (Innes 1983). Further, the social and ecological barriers to accumulation provided by earlier economies were overcome in each case by creative destruction on the part of new landowners (Johnson and Lewis 1995). O'Connor's (1996) crises of underproduction are suggested by the environmental transformations of the pre-20thcentury period, but the absolute limits posited in the second contradiction thesis seem nowhere in evidence.

Nor does the rise of the hunting regime specifically, with its consumption orientation, seem to have a parallel in green materialist approaches. The restoration of indigenous deer species as a strategy for accumulation poorly fits the cycles of degradation described by James O'Connor. Here, nature itself becomes seen as a source of value in its preserved state. Even while this nature is produced from whole cloth, it represents what Escobar (1996) describes as a "postmodern" form of ecological capital: nature produced but preserved for consumption in an increasingly globalized market. Moreover, these new deer economies rose right alongside the previous sheep economy, never entirely displacing it, allowing modern and postmodern capital to "coexist schizophrenically in the same geographical and cultural region," free from immediate contradiction (Escobar 1996:56).

It is this simultaneity of competing management regimes-this schizophrenia-that most defines the economic and ecological transformation of the region, as well as the political and discursive struggles that undergird them. The return of forests in the 20th century proved to be no less schizophrenic.

\section{Highland Forests Re-emergent amidst Restructuring}

Originally covering at least $50 \%$ to $60 \%$ of the land at its height, woodland in Scotland had receded significantly by the end of medieval period, especially as a result of clearance for fuel, agriculture, and grazing (Smout 1993; Turnock 1995). In the following years, as sheep pasturage and deer forests expanded, forests became increasingly scarce (Smith 1993), and following the growth in timber extraction 
during World War I, coverage finally reached a low of roughly $5 \%$ by the 1920s (Forestry Industry Council of Great Britain 1998). In this context, the British government formed the Forestry Commission in 1922, with the aim of conserving existing stocks and expanding total timber production. Between 1922 and the 1990s, Scotland's forested land tripled (Mather and Thomson 1995), expanding over the period at a rate surpassing that in Wales, England, and the UK as a whole (Table 1).

We argue that the forms these forests have come to take, and the struggles over their creation and establishment, inform larger questions of the relationship between economic crisis and ecological change. For, in the wake of economic restructuring in Scotland, two forms of forestry have emerged, each striving to produce differing forest types and each responding to the crisis of restructuring in a different way.

This well-documented restructuring of Scottish economy took the form of dramatic industrial decline, from which the Highlands was not immune. Just as in the rest of the country, jobs in manufacturing, energy, construction, and banking all declined precipitously during the 1990s (Table 2). At the same time, employment in primary production (including forestry and fishing) and some tertiary sectors (distribution, hotels, and restaurants, and other services, including those related to tourism) showed signs of growth (Black 2000). In this context, reforestation provided the state with an area for investment and expansion, even in the face of crisis.

\section{Forests of Production: Conservation Monoculture}

The majority of woodland in Scotland consists of commercial extractive forestry. Most forests were planted and restocked through deliberate programs directed by the Forestry Commission. But private efforts followed state-led ones, and, following the return to government of the Conservative Party in 1979, privatization was enshrined as a state policy for government subsidy of afforestation on private land (Mackay 1990; Mather 1986; Shucksmith 1988). Private

Table 1: Land under Forest, 1924-1990

\begin{tabular}{lcclc}
\hline & Scotland & Wales & England & UK \\
\hline 1924 & 5.6 & 4.9 & 5.1 & 5.3 \\
1947 & 6.7 & 6.2 & 5.8 & 6.1 \\
1965 & 8.5 & 9.7 & 6.8 & 7.7 \\
1980 & 11.9 & 11.7 & 7.3 & 9.3 \\
1998 & 15.6 & 12.0 & 7.6 & 10.7 \\
\hline
\end{tabular}

Note: All figures as percent of total.

Source: Forest Industry Council of Great Britain (1998). 
Table 2: Employment Structure, Scottish Highlands and Islands, Excluding Farming/Crofting

\begin{tabular}{|c|c|c|c|c|}
\hline $\begin{array}{l}\text { Industry } \\
\text { (92 SIC) }\end{array}$ & 1991 & 1997 & Change & $\begin{array}{l}\text { Percent } \\
\text { Change }\end{array}$ \\
\hline Agriculture, Fishing, and Forestry & 5,800 & 8,400 & $+2,600$ & +45 \\
\hline Energy and Water & 2,800 & 1,500 & $-1,300$ & -46 \\
\hline Manufacturing & 17,200 & 13,600 & $-3,600$ & -21 \\
\hline Construction & 9,300 & 9,000 & -300 & -3 \\
\hline Distribution, Hotels, and Restaurants & 35,000 & 36,100 & $+1,100$ & +3 \\
\hline Transport and Communications & 9,400 & 8,400 & $-1,000$ & -11 \\
\hline Banking, Finance, and Insurance & 13,400 & 12,700 & -700 & -5 \\
\hline Public Admin, Education, and Health & 38,600 & 38,300 & -300 & -1 \\
\hline Other Services & 5,800 & 6,300 & +500 & +9 \\
\hline TOTAL & 137,400 & 134,400 & $-3,000$ & -2 \\
\hline
\end{tabular}

Source: Black (2000).

ownership of forests (see Table 3) rose from 410,000 ha in 1984 to 705,000 ha by 1998 (Mather 1987).

These commercial forestry plantations, whether public or private, are dominated by conifers, especially exotics, such as Douglas fir (Pseudotsuga menziesii), Norway spruce (Picea abies), and Sitka spruce (Picea sitchensis), a species introduced from Canada in the 19th century and referred to as a "super tree" for its speed of growth and tolerance of rough climate (Forestry Industry Council of Great Britain 1998). All are construction species with high yield per hectare and capital value. Such plantations are typically harvested through clearcutting, with the total volume of the timber harvest averaging 2,860,000 $\mathrm{m}^{3}$ between 1990 and 1995 (Scottish Office 1998). Although indigenous Scots pine is evident in some of these enclosures, overall tree species diversity is relatively low. Likewise, the population and diversity of fauna is limited, due to the density of plantation. In its ecology, observers have likened this commercial greening of Scotland to the expansion of banana or rubber plantations in earlier international imperial projects (Kaye 1990; Mather 1986).

Table 3: Land under Forests in Scotland (1998)

\begin{tabular}{llccr}
\hline & Conifer & Broadleaf & Other & $\begin{array}{c}\text { Total } \\
\text { Forest }\end{array}$ \\
\hline Forestry Commission & 463 & 6 & 28 & 497 \\
Private woodland & 526 & 115 & 65 & 705 \\
Total & 989 & 120 & 93 & 1,202 \\
\hline
\end{tabular}

Note: All amounts in thousands of hectares.

Source: Forestry Industry Council of Great Britain (1998). 
In the restructuring crisis and state response, we again see the potential explanatory power of a materialist ecological critique. Contrary to the predictions of forest-transition theorists, the rise of forests is in no way passive; instead, it requires a significant fostering effort on the part of the state. Moreover, the return of forests is tied closely to restructuring occurring at an international scale. As green Marxists might predict, declines in forest during previous eras of economic growth have created barriers to present-day expansion, requiring massive interventions to compensate for declining productivity. O'Connor's thesis arguably accounts for the increasing demands on ambient ecosystems (eg forests) resulting from crises and demands in other areas of production (eg manufacturing).

\section{Forests of Consumption: The New Caledonian Woodland}

Yet, if much of the forest sector represents the commercial extractive forestry of production, an increasing proportion of Highland forest is something else entirely. The dramatic increase in commercial forestry has coincided with an expansion of native Caledonian woodland, which, according to the Forestry Industry Council of Great Britain, consists of locally native species and, unlike commercial production forests, is typically dominated by Scots pine, silver birch, alder, and various indigenous tree species (Table 4) (Forestry Industry Council of Great Britain 1998).

This "new" form of forest cover is deliberately planted with assistance from the state's Woodland Grant Scheme (WGS), which contributes money for forest reclamation on private and public woodlands (Forestry Industry Council of Great Britain 1998). In the 1990s, some 24,386 ha of newly planted forest land-around $13.41 \%$ of all new planting-occurred in native woodland plantations, with the vast majority $(90.99 \%)$ carried out on private land (Forestry Industry Council of Great Britain 1998).

The Caledonian Pinewoods Inventory shows that there are some 17,882 ha of already existing native woodlands in Scotland, with an

Table 4: Emergent Forest Ecologies Compared

\begin{tabular}{llll}
\hline $\begin{array}{l}\text { Commercial "Production" } \\
\text { Forest Species }\end{array}$ & $\begin{array}{l}\text { Average } \\
\text { Yield } \\
\left(\mathbf{m}^{3} / \mathbf{y r}\right)\end{array}$ & $\begin{array}{l}\text { Caledonian } \\
\text { "Consumption" } \\
\text { Forest Species }\end{array}$ & $\begin{array}{l}\text { Average } \\
\text { Yield } \\
\left(\mathbf{m}^{3} / \mathbf{y r}\right)\end{array}$ \\
\hline Sitka spruce (Picea sitchensis) & 13 & $\begin{array}{l}\text { Scots pine } \\
\text { (Pinus sylvestris) }\end{array}$ & 9 \\
Norway spruce (Picea abies) & 12 & $\begin{array}{l}\text { Silver birch } \\
\text { (Betula pendula) }\end{array}$ & 5 \\
Douglas fir (Pseudotsuga menziesii) & 14 & $\begin{array}{l}\text { Alderwood (various) } \\
\text { NA }\end{array}$ \\
\hline
\end{tabular}

Source: Forest Industry Council of Great Britain (1998). 
additional 30,000 ha of new forests (Scottish Forestry Commission 1999). Of this coverage, some 15,386 ha are protected as Sites of Special Scientific Interest (SSSI), areas specifically set aside for national preservation status (Scottish Executive 1999b). They are actively protected from sheep- and deer-grazing by the Deer Commission, which makes "vigorous use of its powers, including if necessary its powers of compulsion, to prevent damage and deterioration to land as a result of deer grazing" (Scottish Executive 1999). Thus, while some forests persist as remnants of the past, their expansion clearly represents deliberate state investment, management, and protection.

\section{Constructing a Forest: The Case of Spey}

The Forest of Spey, located on the fringe of the Cairngorms and proximate to key tourist attractions within the Highlands, such as Aviemore, is an excellent example of such efforts. Made up of scattered remnants of ancient Caledonian forest, Spey includes plantations grown in and around these remnants and areas of natural regeneration of both indigenous Scots pine and nonnative conifers. Managed by the Cairngorms Partnership Board, a management authority assembled by the Secretary of State for Scotland to oversee restoration of the Highlands, the forest has become the focus of an ambitious collaborative effort between the public and private sector in a project involving local companies, the Forestry Commission, SNH, the Cairngorms Partnership, the Highland Council, and the Rural Affairs Department of the Scottish Executive.

Since the authority of the partnership board is limited and the project is based on voluntary compliance of stakeholders, reforestation requires careful cooperation between historically reluctant parties. For example, deer populations in the surrounding areas must be managed at levels and densities that allow for the regeneration of native woodland. This requires the cooperation of the Deer Commission, the statutory adviser to the government on all deer matters in Scotland (Torley 2000).

Within the forest, as shown in Table 5, around 70\% of the land was in native pine and birchwood in 1994, outnumbering exotic species planted in the Spey woodlands by a ratio of more than 2 to 1 (Cairngorms Partnership 2001). Nonetheless, since 1994, substantial areas of plantation and "approved regeneration" zones have been opened in Spey, including around 1,700 hectares of pinewood and 3,000 hectares of broadleaves, predominately birch. The overall vision is to increase the cover of these native forests in order to create a landscape where woodland cover is extensive and "visually dominant," thereby enabling further conservation and plantation with the aim of connecting Spey with forests in adjacent watersheds (Torley 2000). 
Table 5: Summary from the Native Woodlands of Strathspey, 1994

\begin{tabular}{lrrr}
\hline Category & Self-sown & Planted & Total \\
\hline Pinewoods & 13,371 & 14,862 & 28,233 \\
Birchwoods & 6,483 & 6,736 & 13,219 \\
Other native broadleaves & 340 & 327 & 667 \\
Nonnative conifers & 4,195 & 0 & 4,195 \\
Mixed conifers and broadleaves & 166 & 0 & 166 \\
Total & 24,555 & 21,925 & 46,480 \\
\hline
\end{tabular}

Note: All amounts in hectares.

Source: Torley (2000).

Promoted as an example of the future of sustainable, working forests, the Forest of Spey is a prominent example of the new "native" landscapes existing schizophrenically alongside the more extensive commercial monoculture plantations. It is being produced at great public and private expense, including the cooperation of historically antagonistic interests, who face a restructured economy and see economic opportunities in the return of "native forest."

The return of Scots-pine woodlands are not, therefore, the result of disintensification or neglect, as forest-transition theorists might suggest. Instead, "native" woodlands, such as Spey, represent a form of nature produced through political and economic processes to overcome the limits placed on the economy by previous environmental transformations. Following O'Connor, the expansion of Caledonian forests demonstrates the struggle of capital to overcome the limits it has imposed on itself through environmental degradation. Moreover, following Escobar (1996), in an era in which preservation invests value in pristine, in-situ nature, the development of these forests comes to be specifically intended for direct consumption as wild space, even though these forests must be produced through evident political effort. Caledonian forest development suggests the formation of capital in its postmodern ecological form.

\section{Economics of Ecological Capital}

The simultaneity of forestry in Scotland suggests two separate economic logics at work. Although the logic behind extractive forestry needs little elaboration, the value of "native" forests deserves some attention. Given the significance of tourism in Scotland, the most direct instrumental value of native forests seems to come in the form of tourism receipts. The country's largest private-sector employer, the Scottish tourism industry is based upon the attraction of around ten million UK visitors and around two million overseas visitors, who contribute around $£ 2,500$ million to the Scottish economy each year 
Table 6: Receipts from Tourism in Scotland

\begin{tabular}{lrr}
\hline & $\mathbf{1 9 7 0}$ & \multicolumn{1}{c}{$\mathbf{1 9 9 8}$} \\
\hline Overseas tourists (in thousands) & 620 & 2,000 \\
UK tourists (in thousands) & 12,300 & 9,800 \\
Tourism revenue from overseas (in millions £ 1998) & 230 & 940 \\
Tourism revenue from UK (in millions £ 1998) & 1,500 & 1,540 \\
Employment & 112,000 & 177,000 \\
\hline
\end{tabular}

Source: Scottish Executive (2000).

(Table 6). As a result, tourism is a major source of employment in Scotland: in the Highlands, almost one-quarter of all jobs are found in the distribution, hotels, and restaurants sector, making it second only to the public administration, education, and health sectors (Table 2).

The relationship between the tourism industry and native forests is emphasized by policy documents published by the new Scottish Executive. Its recent tourism strategy outlines how Scotland's tourism initiatives should build upon what it describes as the country's assetsthe scenery and native environment-capitalizing on its environmental image by maintaining an unspoiled environment (Scottish Executive 2000).

But, as with previous transformations in the Scottish economy, the growth of the tourism industry is hindered by the landscapes produced during previous epochs of accumulation. The "magnificent scenery" is marred by over a century of commercial harvesting. A total of 3,650,000 $\mathrm{m}^{3}$ of timber was harvested in Scotland during 1996 alone, and as more than half of Scotland's forests are under thirty years old, the next 15 to 20 years could produce twice as much (Scottish Executive 1999a; Scottish Office 1998). As extraction in commercial forestry is managed almost exclusively through clear-cutting, there are obvious contradictions between the drive to attract the green tourist and the harvesting of a commercial-forestry sector. Commercialforestry landscapes are an entirely unsuitable context within which a pristine commodity can be sold.

Consequently, the production of alternative forests is viewed as an avenue through which green tourist capital can be captured, with Scots-pine woodlands offering the ideal alternative forest. The reemergence of native forests thus reflects an economy increasingly reliant on tourism-a branch of capitalist production in which "authentic" landscapes are demanded by the tourist gaze (Urry 1990), which holds a preference for "authenticity rather than 'fact,' for the believable over the actual" (McCrone, Morris, and Kiely 1995:8). In this way, native woodlands become a commodifiable artifice, just like 
other museological effects or period construction techniques typically found in manufactured heritage landscapes across the country.

\section{Discursive Forestry}

But given that such consumption forests must expand, why does indigenous Scots pine dominate in species mixes, and what makes the consciously indigenous character of the species mix so important? To answer this question, it is necessary to move beyond the instrumental logic of material value and recognize the discursive value that such forests return within the larger political and discursive turn towards environmental forms of consumption and nationalist forms of collective identity emergent in the late 20th century.

Writing for Audubon while volunteering his time with Trees for Life to plant Scots pine in Glen Affric near Loch Ness, nature writer Guy Hand (2000:30) asks, "[C]an we ever sustain the devotion, humility, and intelligence required to coax a forest from empty ground-and then to keep it there?" In Hand's journal of the event, as in other environmentalist accounts of the reforestation of the Highlands, replanting takes the form of a profound moral and normative crusade. Environmental groups struggling to return the forest see themselves in near-religious terms: "[S]itting in that tight circle on that empty slope," Hand (2000:30) writes, "we look like nothing so much as prayerful druids in Gore-Tex." As Shaul Cohen (1999) insists (following Slater 1996), the language of such conservation groups becomes "Edenese," suffused in nostalgia and dependent on a linkage between trees and generalized environmental good.

Highland conservationists count among their opponents the previous transformers of Scotland-the deer-stalking estate owners. These they are quick to identify as operating in a mistaken "Highland mystique," unlike the authentic and moral interventions of groups such as Trees for Life that have planted a quarter-million trees in the region since 1991. By enforcing the moral value of trees-specifically indigenous trees-the conservation account acknowledges the constructedness of the deer-stalking landscapes of the estate owners without simultaneously problematizing its own vision of the land, reserving for itself the moral high ground on which to plant.

So too, in his account for Audubon, Hand (2000:26) follows other conservationist conventions that place specific blame for degradation at the feet of the British Empire, noting that "[The forest fell] because as Britain became a colonial power it saw anything untamed as an obstacle to its fevered dash toward the future." Thus, Edenic return through reforestation is tied to a lashing-out against the perceived injustice and emasculation of a nation under the ravages of imperial rule. In the return of Scots pine, there is also evidence of collectivist striving, rendered palatable in a moment of emergent nationalism. 
Most prominently, in its efforts to restore a Scottish collective ecology to the highlands, SNH has been a crucial player. Formed in the early 1990s from the former Nature Conservancy Council for Scotland, SNH is funded through the central government; it received $£ 37.203$ million in 1998-1999. Directed by a board of eminent scientists, $\mathrm{SNH}$ is responsible for managing and monitoring historical and environmental resources for Scotland, and represents itself as the conservation agency of the nation (Scottish Natural Heritage 2001).

Despite scientific ecologists warning against the use of terms such as "native" or "alien" in the description of landscape change (Brown 1997), conservationists in the highlands, especially those in $\mathrm{SNH}$, commonly deploy such language, along with claims towards the collective, as in "our natural heritage." Calling on a collective past using nationalist rhetoric in this way, SNH capitalizes on the symbolic value of Scots-pine forests to neutralize opposition to landscape change from opponents, including local crofters and the sporting estates (MacDonald 1998). In so doing, SNH and other environmental activists castigate past ecologies as forms of degradation, exogenous in origin. Hand (2000:27) notes simply, "[Scotland] today is one of the most degraded, deforested lands in the world."

For the re-emergence of Caledonian forests, this emphasis on the shared history of "native" culture and ecology means reading past economic and landscape transformations as foreign. Casting the loss of Caledonian forest in the context of invading sheep and deer enables new plantation efforts to be seen as a matter of recovery after decline. "A tacit implication" of this version of the past, according to Toogood (1995:106), "is that this is unique nature in a unique land ... The nature is native and its decline parallels the loss of self-determination by the Scottish people." In this way, previous landscapes become "degraded," "misused," and "abused," and conservation projects carry moral weight as they transform the land (Bryant 2000).

Moreover, as MacDonald (1998) has observed, these moral geographies of ecological nationalism are not simply rhetorical vehicles to protect bureaucratic budgets and programs; they also represent discursive resources that serve to nullify opposition within the highlands. In particular, opposition to reforestation efforts have come from small-holding Highland agricultural and pastoral producers, known as crofters, and from the traditional holders of deer-sporting estates. These groups have staged their own discursive struggles against landscape change. Crofters hold, for example, that SNH favors birds and animals over "traditional" people, and they offer an agrarian image of the highlands in opposition to that of forested wilderness (MacDonald 1998; Rennie 1991). Sporting estates, threatened by fencing and enclosure, offer their own view of traditional Scotland, 
with the red deer and open heath figuring prominently (Toogood 1995; Trevor-Roper 1983; Urry 1992).

SNH has responded with discursive attempts to ally themselves with opposing groups. The Northern Strategy and Operations Director for the $\mathrm{SNH}$ insists, for example, that "crofters and environmental interests have a very strong common agenda" and that conservation will create economic activities for highlanders (Watson 2000). At the same time, SNH continues to emphasize the collective "traditional" and "Scottish" nature of new forests, portraying them as landscapes destroyed by "English modernity" (MacDonald 1998).

In summary, by appealing to the normative imagination of how the Highlands ought to appear and an instrumental logic of how the region fits in the national economy, the Scottish state has created the momentum for landscape change. This is not to say that discourse alone drives land-cover transformation, but instead to demonstrate the invented culture within which new landscapes are rendered native. SNH and the Scottish Executive have created forests-as mental categories, discursive tropes, and material realities-where, arguably, none have existed before. In this way, they have established paper forests (Robbins 1998): an imaginary geography (Toogood 1995) for an imagined community (Anderson 1991) in an imagined Scotland (Gold and Gold 1995). The re-emergence of Scots pine reveals the discursive forces, as well as economic instrumentalities, of landscape change.

\section{Discussion: The Schizophrenia of Capitalist Ecology}

The dynamics of highland landscapes since 1800 clearly point to the role of broad economic forces in the creation and recreation of landscapes; the rise and fall of commodity and labor markets has sparked massive land-use changes and new environments as a result. Even so, something more complex than broad structural forces rewriting the highland landscape is in evidence here. Specifically, in the re-emergence of forest in the Highlands, we do not simply see the deployment of monocultural production systems that exploit and deplete biodiversity, since biodiverse Caledonian forests are very much on capital's agenda and new conservation interests force their visions of wilderness onto previously unforested heathland. Neither, however, has one form of ecology, that of production, been wholly replaced by another, that of consumption. Indeed, both such kinds of forests are now spreading across the landscape. It is the very simultaneity of these emergent ecologies that suggests richer understandings of the role of the economy in land-cover change. To explore these understandings requires a redirection of ecological critique from a focus on time to a concentration on space. 


\section{Capitalist Ecological Critique and Temporality}

In green Marxian theorization, the key contradictions are temporal. That is, for Foster's (2000) metabolic rift or O'Connor's (1996) second contradiction to take hold, accumulation must draw on the social conditions of production at a rate higher than that which natural regeneration occurs, accelerating the tendency towards entropy. Eventually, a moment arrives when depletion of the resource base leads to shortfalls in production. Such notions of the temporal progression and schism are not unique to materialist accounts; there are hints of such understandings in postmodern thinking. The arrival, after all, of postmodern ecological capital is predicated on a model of socioeconomic succession in which one form of ecology follows another and new environmentalist discourses replace those of productivist modernity.

But the case of the Scottish Highlands complicates matters. Previous environmental regimes clearly do provide barriers to accumulation-for example, where deer populations threaten the growth of new Caledonian forests. But, owing to spatial solutions used to overcome temporal crises, never are these barriers absolute. The shift from sheep pasture in the Highlands, for example, was the result not of local ecological degradation, but rather of the development and export of the sheep economy to New Zealand, which enabled the evasion of contradiction and the transformation of the Highlands to deer forests. Similarly, if the state can put noncommercial Scots pine woodland in the place of industrial forests, it is only, after all, because increased extraction is occurring in the Baltic states, Indonesia, and Ghana, where global timber demand has led to rapid decreases in forest cover. Thus, though there remain temporal contradictions within capitalist ecology, capital's ability to play a shell game with externalities makes such processes hard to chart without attention to space. Does capitalist ecology reach exhaustion in the depletion of soil in a single field, in a national farm economy, or in global commodity markets? Grand contradictions demarked at a high level of abstraction demand, therefore, a more explicit attention to the social and economic production of scale (Marston 2000; Smith 1996b).

So too, Escobar's (1996) notion of postmodern ecological capital depends on a temporally centered model. For Escobar, in-situ ecological capital is a new form and a product of the contemporary restructuring of the relationship of elites to preserved nature. But were not the characteristics of postmodern ecological capital as evident in the deer forests of the 1860s as they are in the Caledonian forests of the 1990s? And does the production of these landscapes not reach a state of struggle, contradiction, and crisis in space-where new forests must reclaim old heather-rather than time? Both green Marxian and postmodern political-ecological approaches, while 
greatly informing the problem of emergent landscapes, sacrifice space in favor of time.

\section{Spatial Fixes and Simultaneous Environments}

As historical review reveals, ecological fixes in the Highlands produce spatial opportunities and barriers for later capitalist accumulation, hinting at some of the contradictory effects of environmental change. Sheep-herding, for example, created consolidation and clearance of land into pasturage. When economic crises grew from a global wool glut, however, the cleared and arguably degraded land provided a barrier to adaptation and growth. But this contradiction was overcome, as sheep-farming landscapes were pushed aside to make way for deer-stalking. These heather landscapes were, in turn, afforested during periods of extractive economic growth when commercial forestry ascended in the 20th century. These afforested monocultures were reinvented in their turn to create the leisure-tourist landscapes of late 20th-century green capitalism.

This resembles less O'Connor's pattern of crisis than that offered by Harvey (1982), in which overaccumulation results from the rigidity of fixed capital, and solutions take the form of spatial and ecological transformation. Thus, the (self-)destructive ecology of capitalism creates its own environmental barriers to growth, as eco-Marxists might predict, but so, too, does the economy create the conditions for reinvention of the landscape, even to the point of creating wilderness, as poststructuralists might argue.

Escobar's (1996) "ecological phase" of capitalism, then, seems not so different from previous eras of socionatural production. The restoration and conservation of certain landscapes, after all, means the obliteration of others that are arguably no less natural. As Harvey (1982) observes, to establish a system of accumulation - as where new tourism receipts develop from Scots pine forests-requires that previously fixed capital be set back into circulation; buildings must be razed, or heathland must be plowed or planted in forest.

Moreover, these spatial fixes in the face of crisis create unevenly developed landscapes that are simultaneously geared to production and consumption as different layers of capitalist development vie with one another on the landscape. As Massey (1999:284) observes, apparently contradictory spatial separations and juxtapositions demonstrate the "often paradoxical character of geographical configurations in which—precisely—a number of distinct trajectories interweave and, sometimes, intersect. Space, then, as well as having loose ends, is also inherently disrupted." The resulting environmental outcomes, a jumble of land covers with multiple ecological and economic trajectories, are a product of capitalist development, but in no simple or unidirectional way. 
The power of nature, natural limits, and natural potentialities remains, therefore, very much a part of economic process. Previous metabolic patterns, created through nature/society interaction, are inevitably ill suited to the new socioecological systems to which they later give rise. Thus, cases like that of Scots pine illuminate, as Bridge (2000:253) observes, "the mechanisms by which contradictions express themselves as challenges to accumulation at particular times and in particular places; and how these challenges stem from a failure of existing practices and institutions to ensure continued access to resources or effectively regulate the impacts of production on the environment."

Moreover, such natures are both material and discursive, and the remnant ecological fixes of prior regimes of accumulation that confront changing economies include visions of nature as well as material ecological practices. The romantic images of the Scottish highlands as deerstalking terrain, for example, are ill suited to the demands of nationalists and tourists, as much so as the actual landscapes of heath and heather to which they are linked.

The clear and monolithic trajectories of modernist historical accounts, whether green Marxian or poststructural in character, are shattered and undermined in a world of spatial differentiation. Apparently irreconcilable landscapes emerge alongside one another, born of similar forces, but laid down with contradictory logics. Industrial forests (the distinct monocultural and clear-cut forests of timber production) and Caledonian forests (the diverse wildlands of the environmentalist imaginary) are the simultaneous products of a restructured Scottish economy. The return of diverse forests within the Scottish Highlands-or, indeed, around the world-is therefore best characterized as the spatial product of schizophrenic capitalist ecology.

\section{Acknowledgments}

The authors would like to thank Denis Torley, Project Officer for Forest of Spey and the Cairngorms Partnership, for all of his time and effort on our behalf. We would also like to acknowledge the extremely helpful input of Phil McManus, Gavin Bridge, and the anonymous reviewers of earlier drafts.

\section{References}

Anderson B (1991) Imagined Communities: Reflections on the Origin and Spread of Nationalism. London, Verso Press

Black S (2000) Chapter 3: Selected issues in Scottish economic development. Section A: Economic trends in the Highlands and Islands during the 1990s. Scottish Economic Report. Scottish Executive. http://www.scotland.gov.uk/library3/economics/ser-21.asp (last accessed 29 September 2002)

Blaikie P (1999) A review of political ecology. Zeitschrift fur Wirtschaftsgeographie 43:131-147 
Bridge G (2000) The social regulation of resource access and environmental impact: Production, nature, and contradiction in the US copper industry. Geoforum 31:237-256

Brown N (1997) Redefining native woodland. Forestry 70(3):191-198

Bryant R L (2000) Politicized moral geographies: Debating biodiversity conservation and ancestral domain in the Philippines. Political Geography 19:673-705

Bryant R L and Bailey S (1997) Third World Political Ecology. New York: Routledge

Cairngorms Partnership (2001) Strathspey: Woodland Categories and Areas. Grantown on Spey: Cairngorms Partnership

Castree N and Braun B (1998) The construction of nature and the nature of construction: Analytical and political tools for building survivable futures. In B Braun and N Castree (eds) Remaking Reality: Nature at the Millennium (pp 3-42). New York: Routledge

Cohen S (1999) Promoting Eden: Tree planting as the environmental panacea. Ecumene 6(4):424-446

Cronon W (1995) The trouble with wilderness, or, getting back to the wrong nature. In W Cronon (ed) Uncommon Ground: Rethinking the Human Place in Nature (pp 69-90). New York: W W Norton and Co

De Camino R, Segura O, Arias L G, and Perez I (2000) Costa Rica: Forest Strategy and the Evolution of Land Use. Washington, DC: World Bank

Demeritt D (1994) Ecology, objectivity, and critique in writings on nature and human societies. Journal of Historical Geography 20:22-37

Escobar A (1996) Constructing nature: Elements for a poststructural political ecology. In R Peet and M Watts (eds) Liberation Ecologies: Environment, Development, Social Movements (pp 46-68). New York: Routledge

Forestry Industry Council of Great Britain (FICGB) (1998) FICGB Handbook 1998. Stirling, Scotland: Forestry Industry Council of Great Britain

Foster J B (2000) Marx's Ecology: Materialism and Nature. New York: Monthly Review Press

Gautam M, Lele U, Kartodihardjo H, Khan A, Erwinsyah I and Rana S (2000) Indonesia: The Challenges of World Bank Involvement in Forests. Evaluation Country Case Study Series. Washington, DC: World Bank

Gold J R and Gold M M (1995) Imagining Scotland: Tradition, Representation and Promotion in Scottish Tourism since 1750. Aldershot: Scolar Press

Hand G (2000) Planting on barren ground. Audubon January-February:26-30

Harvey D (1982) The Limits to Capital. Oxford: Basil Blackwell

Innes J (1983) Land-use changes in the Scottish Highlands during the 19th century: The role of pasture degeneration. Scottish Geographical Magazine 99(3):141-149

Johnson D L and Lewis L A (1995) Land Degradation: Creation and Destruction. Cambridge, MA: Blackwell Publishers

Kaye K J (1990) Use of the countryside by the urban state: Scotland's northwest seaboard and islands. Scottish Geographical Magazine 106(2):89-98

Kepe T and Scoones I (1999) Creating grasslands: Social institutions and environmental change in Mkambati area, South Africa. Human Ecology 27(1):29-54

Kumar N, Saxena N, Alagh Y and Mitra K (2000) India: Alleviating Poverty through Forest Development. Washington, DC: World Bank

Lele U, Viana V, Verissimo A, Vosti S, Perkins K, and Husain S A (2000) Brazil: Forests in the Balance: Challenges of Conservation with Development. Washington, DC: World Bank

MacDonald F (1998) Viewing Highland Scotland: Ideology, representation and the "natural heritage." Area 30(3):237-244

Mackay D G (1990) Rural land use in Scotland: A review of the 1980s. Scottish Geographical Magazine 106(1):12-19 
Marsh G P (1965) Man and Nature: Or, the Earth as Modified by Human Action. Cambridge, MA: Belknap Press, Harvard University Press

Marston S A (2000) The social construction of scale. Progress in Human Geography 24(2):219-242

Marx K (1967a) Capital, vol 1. Translated by Samuel Moore and Edward Aveling. Edited by Frederick Engels. New York: International Publishers

Marx K (1967b) Capital, vol 2. Translated by Samuel Moore and Edward Aveling. Edited by Frederick Engels. New York: International Publishers

Massey D (1999) Spaces of politics. In D Massey, J Allen, A J Sarre and P Sarre (eds) Human Geography Today (pp 279-294).Cambridge, UK: Polity Press

Mather A S (1986) The greening of Scotland. Scottish Geographical Magazine 102:181-186

Mather A S (1987) The structure of forest ownership in Scotland: A first approximation. Journal of Rural Studies 3(2):175-182

Mather A and Needle C (1998) The forest transition: A theoretical basis. Area 30(2):117-124

Mather A S and Thomson K J (1995) The effects of afforestation on agriculture in Scotland. Journal of Rural Studies 11(2):187-202

McCrone D, Morris A and Kiely R (1995) Scotland—the Brand: The Making of Scottish Heritage. Edinburgh: Edinburgh University Press

Meyer W B and Turner B L II (1994) Changes in Land Use and Land Cover: A Global Perspective. Cambridge, UK: Cambridge University Press

Mitchell D (1998) Writing the Western: New Western history's encounter with landscape: Ecumene 5(1):7-29

O'Connor J (1996) The second contradiction of capitalism. In T Benton (ed) The Greening of Marxism (pp 197-221). New York: Guilford Press

O'Connor M (1994) On the misadventures of capitalist nature. In M O'Connor (ed) Is Capitalism Sustainable? (pp 125-151). New York: Guilford Press

Rennie F (1991) Crofting. In M Magnussen (ed) The Nature of Scotland: Landscape, Wildlife and People (pp 107-116). Edinburgh: Canongate

Richards J F (1990) Land transformation. In B L Turner, W C Clark, R W Kates, J F Richards, J T Mathews and W B Meyer (eds) The Earth as Transformed by Human Action (pp 163-178). Cambridge, UK: Cambridge University Press

Robbins P (1998) Paper forests: Imagining and deploying exogenous ecologies in arid India. Geoforum 29(1):69-86

Rudel T K, Perez-Lugo M and Zichal H (2000) When fields revert to forest: Development and spontaneous reforestation in post-war Puerto Rico. The Professional Geographer 52(3):386-397

Scoones I (1999) New ecology and the social sciences: What prospects for a fruitful engagement? Annual Review of Anthropology 28:479-507

Scottish Executive (1999a) New Forests Boost Rural Employment. Edinburgh: HMSO

Scottish Executive (1999b) People and Nature: A New Approach to SSSI Designations in Scotland. Edinburgh: HMSO

Scottish Executive (2000) A New Strategy for Scottish Tourism. Edinburgh: HMSO

Scottish Forestry Commission (1999) The Caledonian Pinewood Inventory. Edinburgh: The Forestry Commission

Scottish Natural Heritage (SNH) (2001) Policy Summaries: Forestry and Woodland. http://www.snh.org.uk/ (last accessed 29 September 2002)

Scottish Office (1998) Scottish Environment Statistics. Edinburgh: HMSO

Shucksmith M (1988) Current land-use issues in Scotland: An overview. Scottish Geographical Magazine 104(3):176-180

Slater C (1996) Amazonia as Edenic narrative. In W Cronon (ed) Uncommon Ground: Rethinking the Human Place in Nature (pp 114-131). New York: W W Norton and Co 
Smith J S (1993) Changing deer numbers in the Scottish Highlands. In T C Smout (ed) Scotland since Prehistory: Natural Change and Human Impact (pp 89-97). Aberdeen: Scottish Cultural Press

Smith N (1996a) The production of nature. In G Robertson, M Mash, L Tickner, J Bird, B Curtis and T Putnam (eds) FutureNatural: Nature/Science/Culture (pp 35-54). New York: Routledge

Smith N (1996b) The space of flows and the politics of scale. Critique of Anthropology 16(1):63-77

Smout T C (1993) Woodland history before 1850. In T C Smout (ed) Scotland since Prehistory: Natural Change and Human Impact (pp 40-49). Aberdeen: Scottish Cultural Press

Toogood M (1995) Representing ecology and Highland tradition. Area 27(2):102-109

Torley D (2000) Personal communication via fax and email with Project Officer, Forest of Spey Development Project, May-June 2001

Trevor-Roper H (1983) The invention of tradition: The Highland tradition in Scotland. In E Hobsbawn and T Ranger (eds) The Invention of Tradition (pp 15-41). Cambridge, UK: Cambridge University Press

Turner B L, Clark W C, Kates R W, Richards J F, Mathews J T and Meyer W B (eds)(1990) The Earth as Transformed by Human Action. Cambridge, UK: Cambridge University Press

Turnock D (1995) The Making of the Scottish Rural Landscape. Aldershot: Scolar Press Urry J (1990) The Tourist Gaze. London: Sage

Urry J (1992) The tourist gaze and the environment. Theory, Culture, and Society 9:9-26

Walker R (1993) Deforestation and economic development. Canadian Journal of Regional Science 16(3):481-497

Watson J (2000) "Crofting and the Environment: Opportunities for the Future." Speech before the Scottish Crofters Union by Jeff Watson, Director, Strategy and Operations (North), SNH, 31 March 2000. Full texthttp://www.snh.org.uk/news/ speeches/jw-ce00.htm (last accessed 29 September 2002)

Whyte I and Whyte K (1991) The Changing Scottish Rural Landscape 1500-1800. London: Routledge

Williams R (1973) The Country and the City. New York: Oxford University Press

Wilson A (1992) The Culture of Nature. Cambridge, MA: Basil Blackwell

Zimmerer K (1994) Human geography and the "new ecology": The prospect and promise of integration. Annals of the Association of American Geographers 84(1):108-125

Zimmerer K S (2000) The reworking of conservation geographies: Nonequilibrium landscapes and nature-society hybrids. Annals of the Association of American Geographers 90(2):356-369 
Copyright $\odot 2003$ EBSCO Publishing 